\title{
The Influential of Physico-chemical Parameters on the Distributions of Oligochateas (Limnodrilus sp.) at the Polluted Downstream of the Tropical Langat River, Peninsular Malaysia
}

\author{
*YAP, C K; RAHIM ISMAIL, A; AZRINA, M Z; ISMAIL, A; TAN, S G \\ Department of Biology, Faculty of Science, Universiti Putra Malaysia, 43400 UPM, Serdang, Selangor, Malaysia Tel: 603-89466616, Fax: \\ 603-86567454
}

\begin{abstract}
The influential physico-chemical parameters on the spatial and temporal distribution of oligochateas (Limnodrilus sp.) at the polluted downstream of Langat River were studied in comparison to the unpolluted upstream for 10-months sampling from March 1998 to February 1999. Based on the correlation analysis (CA) and multiple stepwise regression analysis (SRA), the distribution, abundance and density of Limnodrilus sp. were almost consistent during the ten time samplings from April 1998 to February 1999. Based on CA, the density and distribution of Limnodrilus sp. correlated negatively with the $\mathrm{pH}$ and dissolved oxygen (DO) while positively correlated with conductivity, biological oxygen demand (BOD), $\mathrm{NO}_{3}, \mathrm{NH}_{3}$, total suspended solids (TSS), chemical oxygen demand (COD) and dissolved concentrations of $\mathrm{Cu}$ and $\mathrm{Zn}$. Based on SRA, most of the above parameters are selected as influential factors in affecting the distribution and presence of Limnodrilus sp. on the tropical river. This indicated that the Limnodrilus sp. is a pollutant resistant worm since they can survive in the poor water quality ecosystem. These results based on CA and SRA signified the resistance and tolerance of Limnodrilus sp. survived at the polluted ecosystem of the tropical river. Hence, Limnodrilus sp. is a good bioindicator of polluted rivers in the tropical ecoregion. @JASEM
\end{abstract}

Benthic macroinvertebrates are found in all rivers and they play crucial roles in organic matter dynamics and trophic energy transfer in river ecosystem (Hershey and Lamberti, 1988). As a group, they are the primary food source for most stream and river fishes. Their taxonomic, habitat and life-history diversity ensure that an array of food types is available to many fish species over the entire annual cycle. They also conduct the less apparent but no less important work of decomposing leaf litter and small particles of organic debris on the stream bottom or in the water column and of grazing stream algae, fungi and bacteria. Benthic macroinvertebrates are of importance to aquatic biologists because they can indicate pollution effects on the river ecosystem. In particular, environmental quality has been assessed with respect to oligochaete species ecology by numerous authors (Brinkhurst, 1967; Brinkhurst and Jamieson, 1971; Lang, 1985; Mason and Parr, 2003). These authors based their findings on the relative abundance of species that are classified as intolerant, moderately tolerant and very tolerant of organic pollution. The changes which take place in benthic species composition with polluted conditions form the basis on which biotic indices of water quality are formulated. In this regard, certain aquatic oligochaetes are of such importance in the biotic index that they are referred to as 'indicator species'.

Earlier report by Azlina et al. (2006) found that the biodiversity of macrobenthic invertebrates of Langat River were affected by physico-chemical factors. However, detailed study and discussion on how abiotic factors influence the distribution of the resistant Limnodrilus sp. has not yet been discussed in the literature. The worm species, Limnodrilus sp. was focused in this study because of two reasons. First, it has been suggested as a bioindicator of polluted river ecosystem in Peninsular Malaysia (Yap et al., 2003a; Azlina et al., 2006). However, its potential use for the bioindication purpose needs further validation. Second, the tolerant worm is a very interesting species from ecotoxicological point of view but how is it to be influenced by physicochemical factors are not clarified in the literature. Therefore, the objectives of this study were 1) to determine the relationships between the distribution of Limnodrilus sp. and physico-chemical factors by using correlation analysis (CA) and 2) to find out the most influential physico-chemical factors affecting the distribution of Limnodrilus sp. by month by using stepwise regression analysis (SRA). The use of SRA had been used to find out the most influential allometric variables affecting the accumulation of heavy metals in Perna viridis (Yap et al., 2003b).

\section{MATERIALS AND METHODS}

Description of the study area: Samplings were conducted from March 1998 to February 1999 at eight sampling sites during day time along the Langat River Basin which is located in Selangor, Peninsular Malaysia (Figure 1). The water flows from the upstream area in Hulu Langat until Kuala Selangor at the downstream area where the Langat River becomes the main river in the basin which flows in a southwesterly direction and drains into the Straits of Malacca. The upstream stations covering stations 1 to 4 were clean ecosystem and there was no oligochaetes found in this part of the river. These four sites were characterized by the presence of cobbles and pebbles and sometimes sand and gravel. There was generally high vegetation coverage at the 
four upstream sampling stations. The other four downstream stations (Stations 5-8), were known to receive anthropogenic impacts due to domestic wastes, paper factory, oil palm plantation and township.

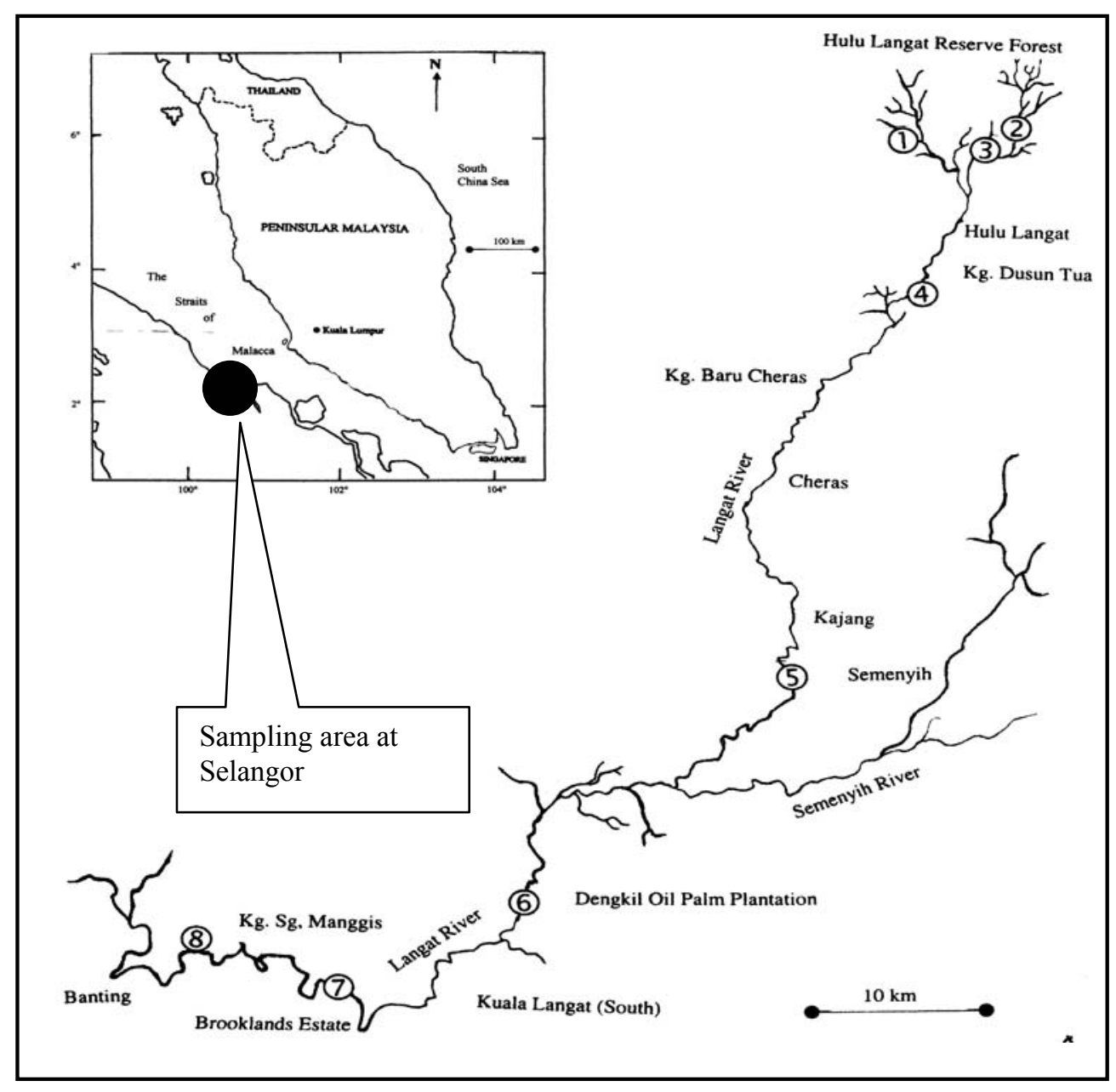

Fig 1: Sampling stations along the Langat River.

Water Quality Measurement and Worm Sampling: Triplicates of the physico-chemical parameters of the river were recorded directly at each sampling site. These were temperature, river depth, river width, conductivity, $\mathrm{pH}$ and dissolved oxygen (DO). River depth and width were measured by direct observation (meter ruler and measuring tape for river width and core for river depth), conductivity and temperature by a YSI meter Model 33, pH by a pH meter Beckman Model F8 253 and dissolved oxygen (DO) by a YSI oxygen meter Model 57. Water samples were collected and analysed for total suspended solids (TSS), dissolved concentrations of $\mathrm{Cu}$ and $\mathrm{Zn}$, nitrate $\left(\mathrm{NO}_{3}\right)$ and ammonia $\left(\mathrm{NH}_{3}\right)$, biological oxygen demand (BOD) and chemical oxygen demand (COD) according to Standard Methods. Limnodrilus sp. were sampled by using a corer sampler $\left(20.83 \mathrm{~cm}^{2}\right)$. The worms were placed in plastic bottles and were preserved with $80 \%$ of ethanol. In the laboratory, the worms were sorted by the naked eyes. Sorting of smaller fauna was done under a dissecting microscope with the aid of watchmaker forceps. All the sorted samples were preserved in new $80 \%$ ethanol before using the appropriate taxonomical keys. The keys used in this study was Brinkurst and Jamieson (1971) for Oligochaeta identification.

Transformation of Data: In order to stabilize the variance so that the data frequency distribution was close to the normal distribution (Sheldon and Haick, 1981), all the physico-chemical data were $\log 10$ transformed while the density of Limnodrilus sp. were fourth-root transformed. Afterwards, Spearman's correlation analysis (CA) and multiple stepwise regression analysis (SRA) would be carried out based on the transformed data to find out the 
most influential variables affecting the distribution of Limnodrilus sp. All the CA and SRA were done by using Statistical Analysis System (SAS) Version 6.0 (SAS, 1987).

\section{RESULTS AND DISCUSSION}

The distribution of Limnodrilus sp. was first interpreted based on CA (Table 1) followed by SRA (Table 2). The CA is important to understand how a single physico-chemical factor affect directly and correlate with the worm distribution. Based on CA, the distribution of Limnodrilus sp. is positively correlated with conductivity, $\mathrm{BOD}, \mathrm{NO}_{3}, \mathrm{NH}_{3}$, TSS, $\mathrm{COD}$ and dissolved concentrations of $\mathrm{Cu}$ and $\mathrm{Zn}$ while they are negatively correlated with the $\mathrm{pH}$ and DO. The negative correlation with these parameters indicated that the worm is a tolerant-pollution species since these water quality parameters are usually included in the determination of water quality index in Malaysia. Based on CA in Table 1, river width and river depth are two physical factors that could positively affect the distribution of the worm species. The worm distribution is generally positively correlated (in some sampling months even significantly) with the river width and river depth. This is due to the downstream sampling sites is usually wider and deeper when compared to the upstream sites which are usually narrower and shallower. Since the downstream received anthropogenic inputs, the wider and deeper river are indirect indicators of polluted downstream sites. This correlated with the high abundance of Limnodrilus sp. at the polluted downstream sites.

Table 1: Spearman's correlation coefficients between Limnodrilus hoffmeisteri and physico-chemical paramaters for 10-months samplings between March 1998-February 1999 in eight sampling sites on Langat River. $(\mathrm{N}=24)$

\begin{tabular}{|c|c|c|c|c|c|c|c|c|c|c|}
\hline $\begin{array}{l}\text { Date of } \\
\text { sampling }\end{array}$ & 180398 & 210498 & 250598 & 230698 & 300798 & 240898 & 261098 & 301198 & 310199 & 310299 \\
\hline $\mathrm{R}$ depth & $0.15^{\mathrm{ns}}$ & $-0.02^{\mathrm{ns}}$ & $0.25^{\mathrm{ns}}$ & $0.79 * * *$ & $0.44^{*}$ & $0.55 * *$ & $0.18^{\mathrm{ns}}$ & $0.77 * * *$ & $0.10^{\mathrm{ns}}$ & $0.64 * * *$ \\
\hline R wid & $0.59 * *$ & $0.70 * * *$ & $0.69 * * *$ & $0.76 * * *$ & $0.50 * *$ & $0.70 * * *$ & $0.52 * *$ & $0.76^{* * *}$ & $0.45^{*}$ & $0.77 * * *$ \\
\hline Temp & $-0.04^{\mathrm{ns}}$ & $0.48 *$ & $0.62 * * *$ & $0.75 * * *$ & $0.74 * * *$ & $0.52 * *$ & $0.53 * *$ & $0.36^{\mathrm{ns}}$ & $0.39^{\mathrm{ns}}$ & $0.21^{\mathrm{ns}}$ \\
\hline Cond & $0.57 * *$ & $0.77 * * *$ & $0.83 * * *$ & $0.77 * * *$ & $0.79 * * *$ & $0.57^{* *}$ & $0.79 * * *$ & $0.70 * * *$ & $0.43^{*}$ & $0.71 * * *$ \\
\hline $\mathrm{PH}$ & $-0.51 * *$ & $-0.45^{*}$ & $-0.54 * *$ & $-0.79 * * *$ & $-0.48^{*}$ & $-0.67 * * *$ & $-0.54 * *$ & $-0.80 * * *$ & $-0.43^{*}$ & $-0.76 * * *$ \\
\hline DO & $-0.56^{* *}$ & $-0.72 * * *$ & $-0.83^{* * *}$ & $-0.76 * * *$ & $-0.46^{*}$ & $-0.61 * * *$ & $-0.77 * * *$ & $-0.78 * * *$ & $-0.46^{*}$ & $-0.77 * * *$ \\
\hline BOD & $0.75 * * *$ & $0.72 * * *$ & $0.20^{\mathrm{ns}}$ & $0.54 * *$ & $-0.22^{\mathrm{ns}}$ & $0.85 * * *$ & $-0.13^{\mathrm{ns}}$ & $0.61 * * *$ & $0.70 * * *$ & $0.84 * * *$ \\
\hline $\mathrm{NO}_{3}$ & $0.81 * * *$ & $0.66^{* * *}$ & $0.63 * * *$ & $0.90 * * *$ & $0.65 * * *$ & $0.82 * * *$ & $0.84 * * *$ & $0.90 * * *$ & $0.80 * * *$ & $0.80 * * *$ \\
\hline $\mathrm{NH}_{3}$ & $0.55 * *$ & $0.77 * * *$ & $0.86^{* * *}$ & $0.90 * * *$ & $0.76 * * *$ & $0.67 * * *$ & $0.71 * * *$ & $0.72 * * *$ & $0.82 * * *$ & $0.57 * *$ \\
\hline TSS & $0.83 * * *$ & $0.84 * * *$ & $0.69 * * *$ & $0.83 * * *$ & $0.44^{\mathrm{ns}}$ & $0.85 * * *$ & $0.51 * *$ & $0.89 * * *$ & $0.78 * * *$ & $0.76^{* * *}$ \\
\hline COD & $0.30^{\mathrm{ns}}$ & $0.24^{\mathrm{ns}}$ & $0.40^{\mathrm{ns}}$ & $0.23^{\mathrm{ns}}$ & $0.25^{\mathrm{ns}}$ & $-0.24^{\mathrm{ns}}$ & $0.39^{\mathrm{ns}}$ & $0.79 * * *$ & $0.74 * * *$ & $0.75^{* * *}$ \\
\hline $\mathrm{WCu}$ & $0.52 * *$ & $0.02^{\mathrm{ns}}$ & $0.51 * *$ & $0.60 * * *$ & $0.41^{*}$ & $0.62 * * *$ & $0.35^{\mathrm{ns}}$ & $0.17^{\mathrm{ns}}$ & $-0.03^{\mathrm{ns}}$ & $0.42 *$ \\
\hline WZn & $0.22^{\mathrm{ns}}$ & $0.54 * *$ & $0.63 * * *$ & $0.55 * *$ & $0.40 *$ & $0.37^{\mathrm{ns}}$ & $0.44 *$ & $-0.04^{\mathrm{ns}}$ & $0.50 * *$ & $0.53 * *$ \\
\hline
\end{tabular}

Note : Levels of significance: $* P<0.05 ; * * P<0.01 ; * * * P<0.001 ;{ }^{n s} P>0.05$.

The density of Limnodrilus sp. was only significantly correlated with temperature in May, June and July $(\mathrm{R}=0.62$ to $0.75 ; \mathrm{P}<0.001)$ and weakly correlated with temperature in April, August and October $(\mathrm{R}=$ 0.48 to $0.53 ; \mathrm{P}<0.01)$. Based on stepwise regression analysis, it was found that temperature is included as an influential factor in affecting the density and distribution of Limnodrilus sp. in April (1998), January (1999) and February (1999). The inconsistency of the temperature as an important parameters was found in only 6 out of 10 sampling periods. These results are interesting since temperature is almost constant $\left(28-31^{\circ} \mathrm{C}\right)$ during daytime in tropical rivers of Peninsular Malaysia but why such results are inconsistent awaits further explanation. The variation and differences in the most influential physico-chemical parameters affecting the distribution of Limnodrilus sp. from month to month indicated three ecological significance. First, although some water quality parameters of Langat River changed from month to month, its distribution is still influenced by the important factors such as $\mathrm{NO}_{3}, \mathrm{NH}_{3}$, TSS, COD and sometimes by dissolved concentrations of $\mathrm{Cu}$ and $\mathrm{Zn}$.

Also, based on SRA, oxygen concentrations of the river (indicated by DO and BOD) are found to be influential factors in affecting the distribution of Limnodrilus sp. These relationships are further validated by $\mathrm{CA}$ in which the Limnodrilus distribution is negatively correlated with DO and positively correlated with BOD. Also, the worm 
distribution is generally influenced by $\mathrm{NO}_{3}$ and $\mathrm{NH}_{3}$. These two nutrients (either $\mathrm{NO}_{3}$ or $\mathrm{NH}_{3}$ ) become important parameters for the distribution of the oligochaetes in eight out of ten sampling months. Based on $\mathrm{CA}$, the worm distribution correlated positively and significantly $(\mathrm{P}<0.01)$ with $\mathrm{NO}_{3}$ and $\mathrm{NH}_{3}$. This indicated that both high levels of nutrients are important factors for the abundance and presence of Limnodrilus sp. and they are resistant benthic macroinvertebrates to these excessive levels of nutrients.

Based on the stepwise regression data of the 10 sampling periods, total suspended solids of five sampling periods were found to be a significant factor to have influenced the distribution and abundance of Limnodrilus spp. Suspended solids are formed by erosion, transportation and deposition of solid materials within a running water are closely linked to current velocity and land-based activities due to human actions. The present results supported the fact that aquatic oligochaete distributions are a recognized indicator of environmental quality. The use of Limnodrilus hoffmeisteri in the study of its tolerance to chemical contaminants has been widely reported in the literature (Chapman et al., 1982; Klerks and Bartholomew, 1991; Martínez-Tabche et al., 1999; Chapman, 2001; Collado and Schmelz, 2001; Flores-Tena and Martínez-Tabche, 2001; Ciutat et al., 2005). For example, Chapman et al. (1982) studied the tolerances of 12 oligochaete species [including Limnodrilus hoffmeisteri] to specific pollutants and environmental factors and to relate tolerances to the use of oligochaetes as indicator species. Species were chosen for experimentation based on their present or potential importance as indicators of organic pollution. The oligochaete assemblages can also indicate the degree of trophy in natural systems (Chapman et al., 1982).

Data from these field studies pointed out that the prediction of ecotoxicological effects requires an understanding of both the physical and biogeochemical pathways controlling metal chemical fate and bioavailability. Among the major processes involved, metal exchanges at the "water column/sediment" interface play a fundamental role along with the storage and release capacities. They are strongly influenced by the physicochemical characteristics of the biotopes but also by biotic factors (Ciutat et al., 2005). Based on multivariate analysis, Collado and Schmelz (2001) found that the distribution patterns of oligochaete species assemblages are significantly correlated with depth, season and substrate. Depth is the major factor when the whole water body is considered. Flores-Tena and
Martínez-Tabche (2001) found that the uptake of chromium by tubificids from artificial and polluted reservoir sediments was found to increase with metal concentration in sediments and exposure time. The increase was higher in experiments with artificial sediment. Cr concentration in worms was related to hemoglobin content, which decreased significantly when $\mathrm{Cr}$ concentrations were above $1.0 \mu \mathrm{g} / \mathrm{g}$ dry weight. In general, all the above reported work supported the fact that the oligochaetes are resistant bioindicators of pollution. At the badly contaminated Foundry Cove of the Hudson River was remarkable for the fact that benthic animals were dense there, despite common sediment $\mathrm{Cd}$ concentrations of 10,000 ppm, the oligochaete Limnodrilus hoffmeisteri apparently evolved a resistance to high concentrations of $\mathrm{Cd}$. Individuals of this species from other areas died soon after being introduced into Foundry Cove sediments, whereas indigenous worms survived well. The resistance seems to have a genetic basis and may be related to the higher production of a metal-binding protein and the ability to precipitate $\mathrm{Cd}$ sulfide in the intracellular organelles (Levinton, 2001). Based on the above phenomenon, the subject on the resistance to heavy metal pollution should prompt future studies.

Conclusion: Since the field conditions consist of multiple abiotic factors, the use of SRA complemented by CA can tell us about the most influential multiple physico-chemical parameters affecting the distribution of the species after these factors are combined in the calculation of the factors. Since the ecosystem is complicated with a lot of abiotic factors interplay with one another, the SRA could therefore more logical for interpretation when compared to CA which is based on one vs one relationship. The results of the present study are of value in elucidating cause-and-effect relationships in field studies of oligochaete pollution distributions in a tropical river. The present data signified the resistance and tolerance of Limnodrilus sp. in the polluted part of the Langat River and therefore they are good bioindicator of such polluted ecosystem since they are found in the poor water quality downstream of the tropical river. However, further studies on its species level and low how to heavy metal pollution at the polluted tropical rivers are necessary. 
Table 2: Relationships of the abundance of oligochaete Limnodrilus spp. based on the results of multiple stepwise regression analysis on physico-chemical data of the Langat River.

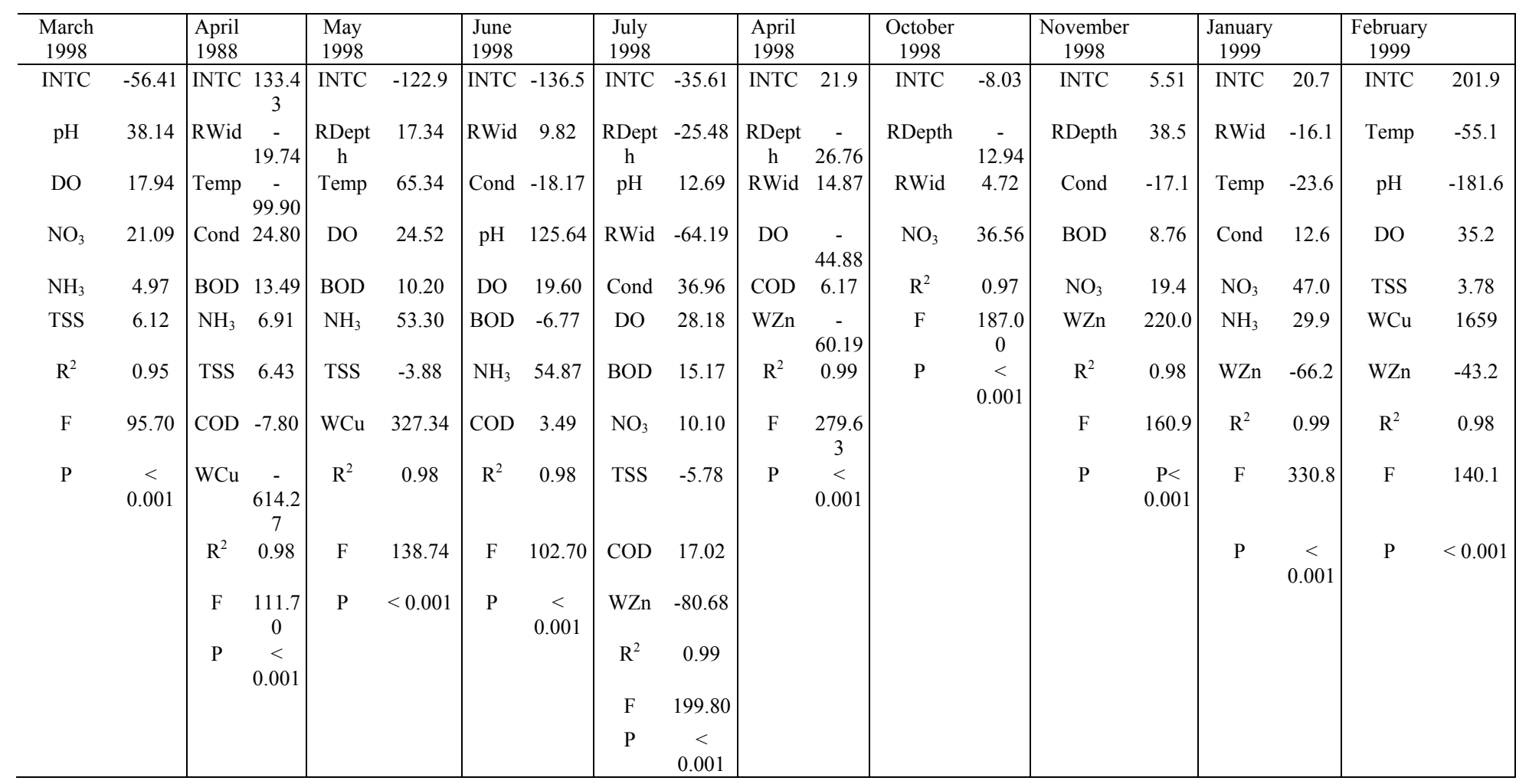

Note: Thirteen physico-chemical parameters are included in the multiple stepwise regression analysis.
$\mathrm{INC}=$ intercept, $\mathrm{DO}=$ dissolved oxygen, $\mathrm{TSS}=$ total suspended solids, BOD= biological oxygen demand, COD, chemical oxygen demand, RDepth= river depth, RWid= river width, temp= temperature, cond= conductivity, WCu= dissolved Cu, WZn, dissolved Zn.

\section{REFERENCES}

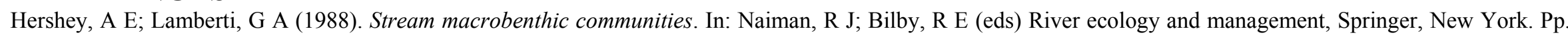
169-199.

Brinkhurst, R O (1967). The distribution of aquatic oligochaetes in Saginaw Bay, Lake Huron. Limnol Oceanogr 12: $137-143$. 
Lang C (1985). Eutrophication of lake Geneva indicated by the oligochaete communities of the profundal, Hydrobiologia 126:237-243.

Mason, C F; Parr, B L (2003). Long-term trends in water quality and their impact on macroinvertebrate assemblages in eutrophic lowland rivers. Wat Res 37:2969-2979.

Azrina, M Z; Yap, C K; Rahim Ismail, A; Ismail, A; Tan, S G. (2006) Anthropogenic impacts on the distribution and biodiversity of benthic macroinvertebrates and water quality of the Langat River, Peninsular Malaysia. Ecotoxicol. Environ. Safety, In press.

Yap, C K; Rahim Ismail, A; Ismail, A; Tan S G (2003a). Species diversity of macrobenthic invertebrates in the Semenyih River, Peninsular Malaysia. Pertanika J Trop Agric Sci 26:139-146.

Yap, C K; Rahim Ismail, A; Ismail, A; Tan S G (2003b). Studies on heavy metal accumulations in green-lipped mussel Perna viridis by using multiple linear stepwise regression analysis. Pertanika J Sci Tech 11:43-55.

APHA, Standard Methods for the examination of water and wastewater. $17^{\text {th }}$ Edition. Washington, American Public Health Association, 1989. Pp.1391.

Sheldon, A L; Haick, A A (1981). Habitat selection association of stream insects. A multivariate analysis. Freshwat Biol 11:395-403.

SAS (1987). Statistical Analysis System: Guide for Personal Computers. Version 6 Edition. SAS Institute Inc., Cary, NC, The United States of America.
Chapman, P A; Farrell, M A; Brinkhurst, R O (1982). Relative tolerances of selected aquatic oligochaetes to individual pollutants and environmental factors. Aquat Toxicol 2:47-67.

Klerks, P L; Bartholomew, P R (1991). Cadmium accumulation and detoxification in a $\mathrm{Cd}$ resistant population of the oligochaete Limnodrilus hoffmeisteri. Aquat Toxicol 19:97-112.

Martínez-Tabche, L; Mora, B R; Oliván, L G; Faz, C G; Ortega, M A G (1999). Toxic Effect of Nickel on Hemoglobin Concentration of Limnodrilus hoffmeisteriin Spiked Sediments of Trout Farms. Ecotoxicol Environ Safety 42:143-149.

Chapman, P M (2001). Utility and relevance of aquatic oligochaetes in ecological risk assessment. Hydrobiologia 463:149-169.

Collado, R; Schmelz, R M (2001). Oligochaete distribution patterns in two German hardwater lakes of different trophic state. Limnologica Ecology and Management of Inland Waters 31:317-328.

Flores-Tena F J; Martínez-Tabche J (2001). The effect of chromium on the hemoglobin concentration of Limnodrilus hoffmeisteri (Oligochaeta: Tubificidae). Ecotoxicol. Environ. Safety 50:196-202.

Ciutat, A; Gerino, M; Mesmer-Dudons, N; Anschutz, P; Boudou, A (2005). Cadmium bioaccumulation in Tubificidae from the overlying water source and effects on bioturbation. Ecotoxicol. Environ. Safety 60:237-246.

Levinton, J S (2001). Marine Biology, Function, Biodiversity, Ecology. 2rd Edition. Oxford University Press, New York. Pp. 474. 